УДК 78.03(477)

DOI: 10.37026/2520-6427-2021-107-3-150-153
Богдан СТОЛЯРЧУК,

професор, завідувач кафедри

музичного фольклору Інституту мистеитв

Рівненського державного

гуманітарного університету,

заслужений діяч мистецтв Украӥни,

м. Рівне, Украӥна

ORCID: 0000-0002-1718-6652

e-mail:kmfim@ukr.net

\title{
МАЛОВІДОМІ СТОРІНКИ ЖИТТЯ МИКОЛИ ЛИСЕНКА НА РІВНЕНЩИНІ
}

\begin{abstract}
Анотація. У статті на основі архівних матеріалів і спогадів представлено факти про перебування та діяльність основоположника украӥнської класичноі музики Миколи Лисенка на Рівненщчині, який проїзом відвідав наш край, прямуючи на навчання до Лейпчига. Окреслено перелік вітчизняних наукових джерел, які допомогли розкрити творчі погляди молодого композитора у прочесі написання нових творів під впливом історичних подій середини ХІХ століття. Основний акиент зроблено на дослідженні творчості композитора та записуванні ним народних пісень під час нетривалих зупинок на Рівненщині. Наведено перелік пісень, записаних Миколою Лисенком у нашому краї,
\end{abstract}

щзо увійтли до його «Збірки народних пісень». Особлива увага приділена літературним та історичним дослідженням, вивченню украӥнського фольклору як невід 'ємної складової украӥнської начіональної класичної музики. Доведено, щзо поштовхом як до виконавської, так і фольклористичної діяльності (збирання народних пісень, їх видання у вигляді композиторських обробок) Лисенка у нашому краї став несподіваний новий зв'язок, про який раніше ніхто не згадував, зокрема участь композитора у роботі Південно-західного відділу Російського географічного товариства.

Ключові слова: Микола Лисенко, хоровий диригент, народні пісні, українська культура, фольклор.

Bohdan STOLIARCHUK,

Professor, Head of Department

of Musical Folklore

of Rivne State Humanitarian University,

Honored Art Worker of Ukraine

Rivne, Ukraine

ORCID: 0000-0002-1718-6652

e-mail:kmfim@ukr.net

\section{RECONDITE PAGES OF MYKOLA LYSENKO'S LIFE IN RIVNE REGION}

\begin{abstract}
The article substantiates the fact of the stay and activity of the founder of Ukrainian classical music Mykola Lysenko at Rivne region. List of Ukrainian scientific sources which is presented, would help to reveal the creative views of the young composer on writing new works under the influence of historical events of the mid-nineteenth century.

Emphasis is placed on the study of his work and recordings of folk songs in determining the purpose and objectives of short-term stops of the composer. Examples of folk songs recorded by Mykola Lysenko, which were included in his "Collection of Folk Songs», are offered.

Considerable attention is paid to literary and historical research and study of Ukrainian folklore, which is an integral part of the Ukrainian National Classical Music. The article presents to the general public not only Mykola Lysenko's stay in the Rivne region, but also his work, recordings of folk songs, which he sought to convey to the general public by performing them on concert stages. Archival documents testifying to his stay in our region, tells about numerous concerts and events in honor of the composer during the
\end{abstract}

20th century and in Independent Ukraine.

Mykola Lysenko, a talented composer and pianistvirtuoso, an outstanding choral conductor, propagandist and researcher of Ukrainian folklore, the founder of art education, could be on the streets of Rivne for several hours, but his observant eye captured quite interesting details of our compatriots' lives. The composer's highest achievement is the opera Taras Bulba, collecting materials for this work, Lysenko visited Dubno, where the main line of the opera takes place.

The impetus for not only performing, but also folklore activities in our region was an unexpected new connection, about which no one had spoken or written before. Lysenko participated in the southwestern branch of the Russian Geographical Society.

Key words: Mykola Lysenko, choral conductor, folk songs, Ukrainian culture, folklore.

Постановка проблеми. Сьогодні, в умовах модернізації вітчизняної культури, одним із напрямів 
удосконалення музичного мистецтва $є$ народна пісня, яка в усі часи живила композиторів своєю неповторною мелодійністю.

На Рівненському Поліссі не одне покоління композиторів, дослідників, етномузикантів, фольклористів захоплювалося прадавньою народно-пісенною культурою. Прекрасні зразки традиційних пісень, обробки яких здійснив свого часу відомий український композитор Микола Лисенко, що деякий час перебував у нашому краї, складають сьогодні репертуар багатьох народних співаків.

У мистецькому житті Рівненщини постать Миколи Лисенка - взірець для сучасників, приклад того, як потрібно служити народові. Період перебування та діяльності композитора на Рівненщині - не лише цікава, а й маловідома сторінка його життя, що потребує нових пошуків і нових досліджень.

Аналіз наукових досліджень і публікацій. Життю та творчості Миколи Лисенка відведено особливе місце в науковій та навчальній роботі митців, дослідників та педагогів нашого краю. Передусім варто згадати книгу «На шляху до Свропи: Микола Лисенко і Рівненщина» (2018), підготовлену до друку Б. Столярчуком, музикантом, поетом, краєзнавцем, автором означеної статті, та С. Полевик, бібліотекарем Рівненської дитячої музичної школи № 1 ім. М. Лисенка. У виданні представлено не лише життєвий шлях і подвижницьку діяльність видатного композитора, а й архівні матеріали та документи, що свідчать про його перебування на Рівненщині.

Творчості композитора присвячено також наукові дослідження В. Кравчука («Вокальна шевченкіана М. В. Лисенка в інтерпретації Модеста Менцинського»), В. Піддубника («Пісні з Волині у фольклористиці М. В. Лисенка», Г. Турчина («Основні принципи музичної педагогіки Миколи Лисенка»), І. Пащука «Весна Лисенкової музики».

М. Афонченко до своєї хрестоматії з диригування «Українська хорова духовна музика» включила твір Миколи Лисенка «Камо пойду», представивши таким чином перемінні розміри, що складають певні труднощі у виборі схем диригування.

К. Устенко підготував та видав навчально-методичний посібник «Микола Лисенко і становлення хорового професіоналізму в Україні», адресований студентам музично-педагогічних факультетів та викладачам хорових дисциплін мистецьких закладів освіти.

Живий свідок життя й творчості Миколи Віталійовича - його син Остап - представив загалу низку науково-популярних праць про композитора, з-поміж яких особливо цінними є «Спогади про батька» (1991). Зі сторінок цієї книги рельєфно виступає щедро обдарована постать одного з найвидатніших творців української демократичної культури - видатного композитора, патріота, дбайливого вихователя мистецьких кадрів, невтомного популяризатора кращих творів народного генія.

Мета статті - схарактеризувати період концертно-виконавської, фольклористичної, популяризаторської діяльності засновника української класичної музики Миколи Віталійовича Лисенка на Рівненщині на основі архівних матеріалів, особистих листів та літературної спадщини.

Виклад основного матеріалу. У вересні 1867 року 25-річний Микола Лисенко прямує на навчання до
Лейпцизької консерваторії. Шлях був неблизьким і складним. Головним «перевізником» того часу на трасі Київ -Житомир був підприємець Пере-Хайм Фельденкрайз. Контора кінських диліжансів містилася в Житомирі (Малаков, 2013).

Величезним двовізним екіпажем на високих колеcax, запряженим у дві пари трійок одномасних коней, Лисенко прямував до Рівного. Шлях пролягав через старовинний Корець, який довелося минати вночі, але «при слабкому світлі місяця показувалися старовинні розвалини замку кн. Корецького, древнього православного південно-руського роду князів, та види і розвалини костелу домініканців, стіни як шпилі чорніли, а деталі затушувались тьмою». Згадуючи про це, Лисенко, мабуть, мав на увазі Воскресенський монастир базиліанів, заснований у 1616 році.

Далі шлях проліг на захід: «Рано вдосвіта проїжджали через містечко Гощу». Тут Лисенко попрохав кучера на якусь мить зупинитися, адже «...3 моста на річці Горині відкрилась безподібна панорама внизу - долина (полог) перерізувана змійкою - Гориною, 3 сінокосами, нивами і все це на горизонті оздоблено вінком вічних лісів. Коли диліжанс виїхав на одну з гірок, внизу з'явилося Рівне - тодішній повітовий центр» (Лисенко М., 2004, с. 15-18).

Годинник уже показував одинадцяту ранку, коли Лисенко, взявши свої речі, вийшов із диліжанса. Невдовзі нагодився й візник, який зголосився довезти приїжджого до його друга Олексія Васильовича Петрова, викладача математики Рівненської гімназії, який проживав у двоповерховому будинку для вчителів (нині - вулиия Драгоманова, $17-Б$. С.). Однак удома його не застав, як і ще одного свого знайомого-полтавця Цисса, проте жінка, яка служила у Цисса, одчинила Лисенкові Олексину хату.

Родина Олексія Петрова вирішила показати гостеві Рівне, яке на той час майже нічим цікавим похвалитися не могло. Для огляду обрали «руїни замку кн. Любомирського», хоча «до цих руїн непросто було добратися» (Малаков, 2013).

Ось як згадує Лисенко про це у своєму листі: «Величезна це будова, видно, велично колись влаштована, судячи по фресках і багатій, вже на половину облупленій і протертій живописі, однак стоїть як свідок давньої слави і сваволі. Багато сходів крутих, із закрутами, місцями цілих, а місцями майже розвалених, ведуть по величезних, почорнілих від часу кімнатах, де кроки наші якось сумно і дзвінко розносились. Найбільше вражала нас заля, страхітливо висока, в два світла, а нижні вікна в ній були зроблені у виді дверей. Стеля вся розмальована, а в центрі іiі зображені Бог-Отець, Син і Св. Дух із трубящими по боках анголами, багато ніш, альковів... Не стало би паперу описати все. Нижній поверх займав склад, та й живуть тут кілька безпомічних бідняків-гімназистів. Один 3 них водив нас по цьому замку...» (Лисенко М., 2004, с. 61).

Увечері Олексій Петров повів Лисенка до Семена Харченка, місцевого посередника. Перед присутніми Лисенко «грав цілий вечір на роялі Брейнкопфа і Гертеля, но він досить глухий і клавіатура нерівна...» (Лисенко М., 2004, с. 157). Нечасто в повітовому містечку можна було слухати гру такого музиканта, як Лисенко.

А вранці наступного дня Лисенко сів писати листа. Описавши наведені вище враження, він зафіксував 
ще й інші факти, адже був досить спостережливою людиною. Про це свідчать такі рядки: «...земля Древлянська... ще і по цю пору являє багато цікавого своїми древніми залишками. А нарід тут зовсім відмінний від нашого по вбранню. Уявіть собі: на них щось ніби киреї довгі і вся грудь вишиті червоними шнурками, як на венгерках, i плечі, і рукави, і розрізи внизу - все облямовано червоними шнурками. На голові тоже конфедератка (в стариків теж) чотирикутна, але роги підняті і загнуті, а посередині шапки невелика китиця. Це дуже оригінальне вбрання і досить гарне. Мужчини між молодими здибаються досить гарні, але закутуються ще більш, як в Сквирі, в чадри» (Лисенко, 2004, с. 250).

Скільки разів довелося побував Лисенку в нашому краї? На це питання важко дати однозначну відповідь. Олена Пчілка, яка була досить добре обізнала в біографії Миколи Віталійовича, у своїх спогадах про композитора підкреслювала, що, «перебувши перший академічний курс своєї науки в Лейпцигу, Лисенко вертався влітку 1868 року в Україну, власне на Полтавщину». За ії словами, восени 1868 року він знову подався до Лейпцига зі своєю молодою дружиною Ольгою Олександрівною. Отже, можливо, шляхи видатного композитора знову могли пролягти через наш край.

Однак незаперечним залишається той факт, що майже добу Лисенко провів у Рівному, ходив його вулицями, знайомився 3 місцевими жителями, залишив описи природи і споруд, а ще надіслав із Рівного власноруч написаний лист - безцінний документ, що $є$ свідченням його перебування у нашому місті.

Найвищим досягненням композитора є його опера «Тарас Бульба», написана за мотивами однойменної повісті Миколи Гоголя. Збираючи матеріали для майбутнього твору, Лисенко навесні 1967 року відвідав старовинне Дубно. Перебуваючи тут, композитор побував у місцях, про які йдеться в повісті, щоб достовірно представити розвиток подій в опері. Ось як згадує син композитора Остап Лисенко про відвідини батьком старовинного міста: «То велика річ, коли композиторові вдається побувати в тих місцях, де колись жили і живуть його герої. Я це по собі знаю. Польські картини в опері майже всі навіяні тим, що я бачив і відчував у Дубно... Годинами простоював Микола Віталійович біля старого замку в дубенського воєводи... Дивився на величезну середньовічну будівлю $з$ чотирма баштами, на поля, де-не-де вкриті лісками, i бачив замок цей в облозі козацькій... Чи не тут, біля ліска, востаннє зустрівся Андрій зі своїм батьком?» (Лисенко О., 1991). За життя композитора на сцені опера так і не була поставлена.

Зв'язок Миколи Лисенка з нашим краєм неабияк прослідковується завдяки його участі у роботі Південно-західного відділу Російського географічного товариства, яке, крім літературних та історичних досліджень, долучилося й до вивчення українського фольклору, зокрема й волинського. У зв'язку з цим Микола Лисенко писав: «Фольклор - це саме життя, ця сфера необхідна людині як повітря, без неї гріх починати свою працю і музиканту, і філологу».

Також композитор підтримував зв'язок із товариством «Дослідники Волині», зокрема брав участь у його археологічних з'їдах, де неодноразово порушувалися питання Волинського краю. Цікавився Микола Лисенко і місцевим фольклором, наприклад, ним із голосу Лесі Українки були записані народні пісні, які поетеса до цього записала у селі Чекна Дубенського повіту. Ці пісні Микола Віталійович упорядкував у «Збірку народних пісень у хоровому розкладі, пристосованих для учнів молодшого і підстаршого віку у школах народних» (Квітка, 1971).

Серед найвідоміших пісень варто виокремити такі: «А в кривого танця», «А в нашої перепілоньки», «А в неділю раненько», «А я рак-неборак», «Кострубонько», «Бідна моя голівонько», «Десь тут була подоляночка», «Женчичок-бренчичок вилітає», «Заїньку, та за голівоньку», «Ой ніхто ж там не бував», «Ой чи диво, чи не диво», «Царівно, ми твої гості», «Чи ви бачили», «Чорнушко, душко» (Лисенко М., 1994).

Із нагоди 100-річчя від дня народження Миколи Лисенка окружна Просвіта у Рівному провела конкурс хорових колективів «Свято української пісні». Тоді ж виступив із концертом хор окружної Просвіти під орудою Юрія Цехміструка, який заспівав «Засяло сонце золоте», «Зеленая ліщинонька», «Котилася зірка», «Туман хвилями лягає», «Птичий хор». Ось як про ці події згадує Улас Самчук у своїй книзі «На коні вороному»: «...у залі кіно «Скеля» - свято пісні, присвячене століттю народження Миколи Лисенка. Виступало п’ять хорів з сіл Глинки, Обарів, Шубків, Городок і самого Рівного... Такі імпрези відбулися по містах, містечках і селах» (Самчук, 1975).

У місті Рівне двоповерхова будівля по вулиці Драгоманова, 17 пам'ятає багатьох відомих митців, видатних діячів вітчизняної культури, чиї життєві та творчі шляхи пов'язані з нашим містом. Тут свого часу побували: письменник Володимир Короленко, історик та етнограф Микола Костомаров, літературознавець і фольклорист Михайло Драгоманов, член Кирило-Мефодіївського братства Петро Чуйкевич, археолог, етнограф, мистецтвознавець Микола Біляшівський, а також основоположник української класичної музики Микола Лисенко. У 1988 р. на будинку по вулиці Драгоманова, 17 на честь видатного композитора була відкрита меморіальна дошка (автор Віктор Дідковський) (Пащук, 2008). Того ж дня відбувся великий концерт, до якого були включені музичні твори Миколи Лисенка. Враженнями від концерту поділилася онука Миколи Віталійовича - відома піаністка, професорка Рада (Аріадна) Остапівна Лисенко: «Сьогодні я ще раз переконалася: народна пісня живе. Це не архаїка. Вона потрібна народові. Лисенко потрібен йому... Зворушена до сліз, бо побачила, що Лисенка треба слухати у Рівному, настільки теплий і сердечний був концерт, сама атмосфера зустрічі, з якою любов'ю поставилися до неї усі без винятку». Зі свого боку композитор Андрій Штогаренко, чоловік Ради Остапівни, зауважив: «Почуваю себе справді на українській землі. Наш музичний побут неабияк знизився, а все тому, що ми відірвалися від національного, рідного. Наше коріння - у народній пісні. Дуже зворушений від концерту. Те, що я сьогодні побачив і почув, було глибоко артистичним і народним за використанням. Хай це свято триває, хай стане традицією».

Через кілька років з ініціативи художнього керівника і диригента Богдана Депо та за участі камерного оркестру Рівненської філармонії у місті відбувся авторський концерт композитора Андрія Штогаренка, на якому прозвучали найвідоміші твори композитора, як-от: «Вірменські ескізи», поема «Пам'яті Кобзаря», 
сюїта «Молодіжна» для струнного оркестру, вокальні твори, а також концерт для флейти і струнного оркестру «Дивертисмент». У концерті брали участь Рада Лисенко та ії донька Наталія, які репрезентували фортепіанні твори Андрія Штогаренка (Столярчук, Полевик, 2012).

У 1992 році, у рік 150-річчя від дня народження Миколи Лисенка, виконавчий комітет Рівненської обласної ради народних депутатів, розглянувши клопотання Обласного управління культури, звернувся 3 проханням до Кабінету Міністрів України щодо присвоєння Рівненській дитячій музичній школі № 1 імені Миколи Віталійовича Лисенка.

Рівненська музична школа № 1 ім. М. Лисенка, один із найстаріших музичних закладів Рівненщини, нині продовжує виховувати нове покоління музикантів, виконавців, майбутніх педагогів. У трьох корпусах школи пізнають світ музики понад тисяча вихованців. Переступивши поріг закладу, неможливо не помітити великий портрет Миколи Віталійовича Лисенка, а трохи нижче слова поета Максима Рильського:

Він од народу набирався сили

В натхненній праці, в боротьбі палкій,

Коли творив щоденний подвиг свій

Во ім'я тих, що сіяли й косили

(Бухало, Матійченко, 2000).

Висновки. Відвідання Рівненщини Миколою Лисенком, основоположником української класичної музики, піаністом-віртуозом, хоровим диригентом, невтомним популяризатором та дослідником українського фольклору, засновником мистецької освіти, хоч і було явищем спонтанним, адже композитор побував у нашому краї, прямуючи на навчання до Лейпцизької консерваторії, однак залишило в душі та серці композитора найтепліші спогади.

Пильне око молодого Лисенка помічало досить цікаві подробиці життя місцевого населення, неймовірну природу нашого краю. Він захоплювався середньовічною красою Дубенського замку та палацу князів Любомирських у Рівному, а ще колоритним місцевим фольклором, про що згодом описав у листі, датованому 11 вересня 1867 року. Як свідчення перебування композитора на Рівненщині - і записані ним пісні, що згодом увійшли до впорядкованої ним «Збірки народних пісень у хоровому розкладі, пристосованих для учнів молодшого і підстаршого віку у школах народних», численні спогади, архівні документи та матеріали, що розповідають про концерти та заходи на честь композитора.

Сподіваємося, що представлені нами матеріали та маловідомі факти із життя Миколи Лисенка допоможуть усім, хто цікавиться життям видатного композитора, по-новому поглянути на цю неординарну особистість.

Перспективи подальших досліджень. Дослідницька робота над архівними матеріалами про перебування Миколи Лисенка на Рівненщині продовжується. Насамперед плануємо грунтовніше дослідити записи народних пісень на Дубенщині, зокрема у селі Чекна, деякі з яких увійшли до збірки «Народні пісні у записах Миколи Лисенка».

\section{СПИСОК ВИКОРИСТАНОЇ ЛІТЕРАТУРИ}

На шляху до Свропи: Микола Лисенко і Рівненщина. (2018) / ред.-упоряд. Б. Столярчук, С. Полевик. 2-ге вид., змін. і допов. Рівне: Волинські обереги. 211 с.

Лисенко, О. (1991). Спогади про батька. Київ: Музична Україна. 315 с.

Малаков, Д. (2013). Із Києва до Житомира на перекладних. День. 17 серпня. С. 1.

Микола Лисенко. Листи. (2004) / відпов. ред. Р. Скорульська. Київ: Музична Україна. 680 с.

Квітка, К. (1971). Музично-фольклористична спадщина Лесі Українки. Спогади про Лесю Українку. Київ: Дніпро. С. 247-256.

Лисенко, М. (1991). Збірка народних пісень в хоровому розкладі, пристосованих для учнів молодшого і підстаршого віку у школах народних. Київ: Музична Україна. 96 с.

Самчук, У. (1975). На коні вороному. Вінніпег: Видавництво товариства «Волинь». С. 197-199.

Пащук, I. (2008). Меморіальні дошки у Рівному: історико-краєзнавчий довідник. Рівне. С. 32-33.

Бухало, Г., Матійченко, В. (2000). Рівне: вулиці, проспекти, майдани: короткий довідник. Рівне: Волинські обереги. $118 \mathrm{c.}$

\section{REFERENCES}

Na shliakhu do Yevropy: Mykola Lysenko i Rivnenshchyna [Mykola Lysenko and Rivne region]. (2018) / red.-uporiad. B. Stoliarchuk, S. Polevyk. 2-he vyd., zmin. i dopov. Rivne: Volynski oberehy. 211 s. [in Ukrainian].

Lysenko, O. (1991). Spohady pro batka [Memories about the Father]. Kyiv: Muzychna Ukraina. 315 s. [in Ukrainian].

Malakov, D. (2013). Iz Kyieva do Zhytomyra na perekladnykh [From Kyiv to Zhytomyr on transfer]. Den. 17 serpnia. S. 1. [in Ukrainian].

Mykola Lysenko. Lysty [Mykola Lysenko. Letters]. (2004) / vidpov. red. R. Skorulska. Kyiv: Muzychna Ukraina. 680 s. [in Ukrainian].

Kvitka, K. (1971). Muzychno-folklorystychna spadshchyna Lesi Ukrainky [Lesya Ukrainka musical and folklore heritage]. Spohady pro Lesiu Ukrainku. Kyiv: Dnipro. S. 247-256. [in Ukrainian].

Lysenko, M. (1991). Zbirka narodnykh pisen v khorovomu rozkladi, prystosovanykh dlia uchniv molodshoho i pidstarshoho viku u shkolakh narodnykh [Collection of folk songs in choral schedule at the folk schools adapted for younger and older students]. Kyiv: Muzychna Ukraina. 96 s. [in Ukrainian].

Samchuk, U. (1975). Na koni voronomu [On a black horse]. Vinnipeh: Vydavnytstvo tovarystva «Volyn». S. 197-199. [in Ukrainian].

Pashchuk, I. (2008). Memorialni doshky u Rivnomu: istoryko-kraieznavchyi dovidnyk [Memorial plaques in Rivne: historical and local lore guide]. Rivne. S. 32-33. [in Ukrainian].

Bukhalo, H., Matiichenko, V. (2000). Rivne: vulytsi, prospekty, maidany: korotkyi dovidnyk [Rivne: streets, avenues, squares. Brief guide]: korotkyi dovidnyk. Rivne: Volynski oberehy. 118 s. [in Ukrainian].

Дата надходження до редакиіï: 24.06. 2021 p. 